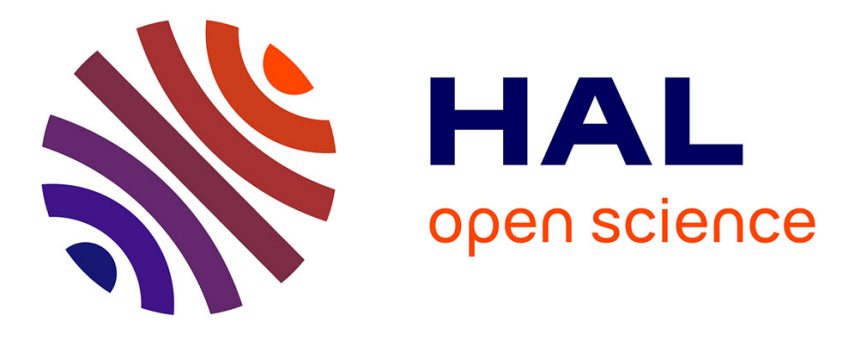

\title{
Sublethal doses of imidacloprid decreased size of hypopharyngeal glands and respiratory rhythm of honeybees in vivo
}

Fani Hatjina, Chrisovalantis Papaefthimiou, Leonidas Charistos, Taylan Dogaroglu, Maria Bouga, Christina Emmanouil, Gerard Arnold

\section{To cite this version:}

Fani Hatjina, Chrisovalantis Papaefthimiou, Leonidas Charistos, Taylan Dogaroglu, Maria Bouga, et al.. Sublethal doses of imidacloprid decreased size of hypopharyngeal glands and respiratory rhythm of honeybees in vivo. Apidologie, 2013, 44 (4), pp.467-480. 10.1007/s13592-013-0199-4 . hal-01201319

\author{
HAL Id: hal-01201319 \\ https://hal.science/hal-01201319
}

Submitted on 17 Sep 2015

HAL is a multi-disciplinary open access archive for the deposit and dissemination of scientific research documents, whether they are published or not. The documents may come from teaching and research institutions in France or abroad, or from public or private research centers.
L'archive ouverte pluridisciplinaire HAL, est destinée au dépôt et à la diffusion de documents scientifiques de niveau recherche, publiés ou non, émanant des établissements d'enseignement et de recherche français ou étrangers, des laboratoires publics ou privés. 


\title{
Sublethal doses of imidacloprid decreased size of hypopharyngeal glands and respiratory rhythm of honeybees in vivo
}

\author{
Fani Hatjina ${ }^{1}$, Chrisovalantis Papaefthimiou ${ }^{2}$, Leonidas Charistos $^{1}$, \\ Taylan Dogaroglu ${ }^{3}$, Maria Bouga ${ }^{4}$, Christina Emmanouil ${ }^{4}$, Gerard Arnold ${ }^{5}$ \\ ${ }^{1}$ Hellenic Institute of Apiculture, Hellenic Agricultural Organization 'DEMETER', N. Moudania 63200 Greece \\ ${ }^{2}$ Laboratory of Animal Physiology, Department of Zoology, School of Biology, Aristotle University, 54124 \\ Thessaloniki, Greece \\ ${ }^{3}$ Mugla University, Science Faculty, Biology Department, 48000 Mugla, Turkey \\ ${ }^{4}$ Lab of Agricultural Zoology and Entomology, Agricultural University of Athens, 75 Iera Odos Str, Athens 11855 \\ Greece \\ ${ }^{5}$ Laboratoire Evolution, Génomes, Spéciation, CNRS UPR 9034, 91198 Gif-sur-Yvette, France and Université \\ Paris-Sud 11, Orsay, France
}

Received 28 August 2012 - Revised 11 January 2013 - Accepted 25 January 2013

\begin{abstract}
Most studies that have shown negative sublethal effects of the pesticide imidacloprid on honeybees concern behavioral effects; only a few concern physiological effects. Therefore, we investigated sublethal effects of imidacloprid on the development of the hypopharyngeal glands (HPGs) and respiratory rhythm in honeybees fed under laboratory conditions. We introduced newly emerged honeybees into wooden mesh-sided cages and provided sugar solution and pollen pastry ad libitum. Imidacloprid was administered in the food: $2 \mu \mathrm{g} / \mathrm{kg}$ in the sugar solution and $3 \mu \mathrm{g} / \mathrm{kg}$ in the pollen pastry. The acini, the lobes of the HPGs of imidacloprid-treated honeybees, were $14.5 \%$ smaller in diameter in 9-day-old honeybees and $16.3 \%$ smaller in 14-day-old honeybees than in the same-aged untreated honeybees; the difference was significant for both age groups. Imidacloprid also significantly affected the bursting pattern of abdominal ventilation movements (AVM) by causing a $59.4 \%$ increase in the inter-burst interval and a $56.99 \%$ decrease in the mean duration of AVM bursts. At the same time, the quantity of food consumed (sugar solution and pollen pastry) per honeybee per day was the same for both treated and untreated honeybees.
\end{abstract}

imidacloprid / honeybee / hypopharyngeal gland / respiratory rhythm

\section{INTRODUCTION}

Scientists are driven to understand the reasons behind globally rising honeybee mortality. The factors that appear to be most important include exposure to pesticides especially insecticides and interactions between pesticides and pathogens (Alaux et al. 2010; Vidau et al. 2011).

Corresponding author: F. Hatjina,

fhatjina@instmelissocomias.gr; fani.hatjina@yahoo.com Manuscript editor: Monique Gauthier
Since 1991, neonicotinoid insecticides have been the fastest-growing class of insecticides used in modern crop protection; they are currently registered in more than 120 countries. Imidacloprid represents the greatest portion of the entire neonicotinoid market $(41.5 \%)$, followed by thiamethoxam and clothianidin (Jesche et al. 2011). These insecticides act on the insect central nervous system (CNS), as agonists of the postsynaptic nicotinic acetylcholine receptor (nAChRs) (Matsuda et al. 2001; Brown et al. 2006). Activation of nAChRs by 
neonicotinoids induces initial depolarization and ultimately suppresses synaptic transmission at the postsynaptic membrane of cholinergic synapses in insects (Benson 1992; Buckingham et al. 1997).

Honeybees are exposed to neonicotinoids in several ways: consumption of contaminated nectar and pollen, contact with pesticides exuded from plants, and exposure to air contamination during sowing. Honeybees are exposed to neonicotinoids through three categories of plants: seed-dressed plants, sprayed plants (for example, in orchards), and any plant in the environment that draws neonicotinoids from contaminated soil can remain contaminated with these insecticides for a long time after treatment (Bonmatin et al. 2003)

Neonicotinoids have systemic properties in the plant, where they disperse from roots to aerial parts during growth. For sunflower seed dressed with imidacloprid, the residues average $1.9 \mu \mathrm{g} / \mathrm{kg}$ in the nectar (Stork 1999) and $3 \mu \mathrm{g} /$ $\mathrm{kg}$ in pollen (Stork 1999) with values ranging from 1 to $11 \mu \mathrm{g} / \mathrm{kg}$ (Bonmatin et al. 2003). For maize seed dressed with imidacloprid, the residues in the pollen range between 0.3 and $18 \mu \mathrm{g} / \mathrm{kg}$, with a mean of $2.1 \mu \mathrm{g} / \mathrm{kg}$ (Bonmatin et al. 2005).

Several studies have confirmed that pollen contaminated with imidacloprid can be brought back to the hive by honeybees in natural conditions. Chauzat et al. (2006) analyzed the pollen pellets collected by honeybees in 25 apiaries placed in different sites in France over five sampling periods (from autumn 2002 to autumn 2003). Residues of imidacloprid and its metabolite 6-chloronicotinic acid were found in $69 \%$ of samples. Concentrations of imidacloprid and 6-chloronicotinic acid in pollen ranged from 1.1 to $5.7 \mu \mathrm{g} / \mathrm{kg}$ and from 0.6 to $9.3 \mu \mathrm{g} /$ $\mathrm{kg}$, respectively. Two further years of study have confirmed these results (Chauzat et al. 2011). Interestingly, statistical tests have revealed no significant differences in contamination frequency for any sampling period or spatial distribution. This suggests that honeybees are continuously exposed to neonicotinoid molecules, either from treated cultivated plants or from other plants that draw imidacloprid in the soil.

Honeybees have intense requirements for fluids (Visscher et al. 1996; Kühnholz and Seeley 1997) and have been reported to collect water produced by plants through guttation/ exudation (Shawki et al. 2005). Exudation is a natural plant phenomenon that causes leaves to excrete xylem fluid at leaf margins. Girolami et al. (2009) showed that leaf exudation drops on all corn plants germinated from neonicotinoidcoated seeds contained insecticide at concentrations that were consistently higher than $10 \mathrm{mg} / \mathrm{l}$, with a maximum of up to $200 \mathrm{mg} / \mathrm{l}$ for imidacloprid; that is, near or even higher than the concentration of active ingredients commonly applied in field sprays for pests. Another way that honeybees are exposed to neonicotinoid insecticides arises when seed-dressed plants are sown and dust disperses from the sowing machine and drifts to the wild vegetation, thereby negatively impacting foraging honeybees (Greatti et al. 2003, 2006; Maini et al. 2010; Girolami et al. 2011; Marzaro et al. 2011).

Studies have demonstrated that low doses of imidacloprid have sublethal effects on honeybees. Most look at behavioral effects, such as effects on learning and orientation (Kirchner 1999; Decourtye et al. 2003, 2004a, b), on foraging activity (Colin et al. 2004; RamirezRomero et al. 2005; Yang et al. 2008), on communication by dances (Kirchner 1999), on homing behavior (Bortolotti et al. 2003; Henry et al. 2012), and on neurophysiological effects (Guez et al. 2001a, b; Lambin et al. 2001).

In contrast, few studies have looked at possible physiological effects of exposure to neonicotinoid insecticides. For this reason, we decided to investigate two possible physiological effects: effects of neonicotinoids on the development of the hypopharyngeal glands (HPGs) and on the functioning of the honeybee respiratory mechanism. All honeybees used in this study were reared under the same experimental conditions.

Adult honeybee workers consume large quantities of pollen, which is needed to enable 
them to produce the royal jelly, the food necessary for larval development (Haydak 1970; Crailsheim et al. 1992). Royal jelly is produced in the HPGs, which are located in the head of the worker honeybee. HPG development begins very early in the life of the adult honeybees, and the glands reach their maximum size and weight when the honeybees are 812 days old (Crailsheim and Stolberg 1989; Knecht and Kaatz 1990; Lass and Crailsheim 1996; Hrassnigg and Crailsheim 1998). When honeybees are older than 12 days, the HPGs decrease in size (Fluri et al. 1982; Deseyn and Billen 2005) and their function changes, a phenomenon that parallels the age-dependant role of the honeybee within the colony (Ohashi et al. 1997). However, the HPGs continue to synthesize considerable amounts of proteins (Knecht and Kaatz 1990) and digestive enzymes like invertase and glucose oxidase (Deseyn and Billen 2005). Thus, HPGs are important to colony growth. As the size of the HPGs change during a honeybee's life, the size of the gland lobes (the so-called "acini") changes accordingly. Therefore, the acini diameter is an indication of the gland's activity and reflects the amount of proteins produced (Knecht and Kaatz 1990). For this reason, the diameter of the acini has been used as an indicator of HPG development under different food or stress conditions (Standifer 1967; Wang and Moeller 1969; Malone et al. 2004; Babendreier et al. 2005; Smodis-Skerl and Gregorc 2010).

Despite the importance of HPGs in honeybees, very little research has looked at the effect of imidacloprid on HPG development. Furthermore, the research performed has concentrated on a short period (1-3 days) of exposure to imidacloprid (Heylen et al. 2010; Smodis-Skerl and Gregorc 2010). Heylen et al. (2010) contaminated 7-day-old caged honeybees with sublethal doses of imidacloprid over only 1 day of exposure. They showed that the HPG acini were all significantly smaller in treated honeybees 1 week post-treatment than in untreated honeybees. Smodis-Skerl and Gregorc (2010) contaminated honeybees of different ages with sublethal doses of imidaclo- prid over 1, 2, or 3 days. They showed a decrease in the size of the HPG acini, even after the shortest treatment time $(24 \mathrm{~h})$.

Respiratory mechanisms in honeybees are mainly mediated by coordinated motor activity (Chapman 1998). This motor activity depends on patterned neural control, which in insects is generated by a Central Pattern Generator (CPG) located in the CNS. This CPG is a neural network of interneurons that provides the rhythms to the motor neurons that supply the respiratory muscles (Ramirez and Pearson 1989; Bustami and Hustert 2000; Nicolas et al. 2005). Efficient communication between different parts of the respiratory network for example, between interneurons and motor neurons, depends on fast cholinergic transmission and, ultimately, on the proper function of insect nAChRs (Breer and Sattelle 1987; Buckingham et al. 1997). Respiration or gas exchange of resting honeybees occurs mostly in discontinuous convective cycles or discrete bursts of $\mathrm{CO}_{2}$ emission that are accompanied by abdominal ventilation movements (AVM), as in other insects (Lighton and Lovergrove, 1990) and as revealed by infrared thermography (Kovac et al. 2007). Similar bursts of AVM have been recorded by using a non-invasive method in restrained immobilized honeybees (Zafeiridou and Theophilidis 2006). The strong imidaclopridinduced activation and subsequent blocking of nAChRs shown ex vivo (Matsuda et al. 2001, 2005; Zafeiridou and Theophilidis 2004) suggests a possible disruption of the respiratory activity of honeybees in vivo. This disruption could affect the honeybee's physiological response to tasks such as foraging, which requires increased oxygen consumption (Wolf et al. 1989).

The scope of this study was to investigate the direct effects of sublethal doses of imidacloprid on HPG development and respiratory rhythm of honeybees kept in laboratory conditions.

\section{MATERIAL AND METHODS}

All honeybees used in this study were Apis mellifera macedonica originally collected from their 
natural distribution area; adult honeybees were collected every $2-3 \mathrm{~h}$ after their emergence from combs kept in an incubator. The temperature in the incubator was $34{ }^{\circ} \mathrm{C}$ and the relative humidity was $70 \%$. Combs from three different colonies were used. Honeybees were randomly assigned to wooden, meshsided cages $(10 \times 10 \times 10 \mathrm{~cm})$ with removable metal floor sheets that facilitated cleaning. Approximately 60 honeybees were placed in each cage (16 cages were used in total). The cages were kept in an incubator in darkness at $28-29{ }^{\circ} \mathrm{C}$ and relative humidity of about $70 \%$. Honeybees were fed sugar solution $(33 \% \mathrm{w} / \mathrm{v})$ via gravity feeders and pollen pastry on pre-weighted plastic plates, both ad libitum. Food provisions were changed every 3 or 4 days.

Imidacloprid in concentrations of $2 \mu \mathrm{g} / \mathrm{kg}$ in the sugar solution and $3 \mu \mathrm{g} / \mathrm{kg}$ in the pollen pastry was administered, which is the average amount found in nectar and pollen of sunflower- and maize-treated crops (Stork 1999; Bonmatin et al. 2003). Pollen pastry was prepared by mixing $700 \mathrm{~g}$ of pollen pellets with $300 \mathrm{~g}$ of sugar solution. Correct amount of imidacloprid was added first to sugar solution and immediately after it was mixed with the pollen in order to form the pollen pastry. The sugar solution and pollen pastry were given continuously, to mimic feeding by the nurse honeybees in the colony. In order to validate the effective concentrations of imidacloprid to which honeybees were exposed, chemical analysis of the pollen pastry and sugar solution using liquid chromatography coupled to mass spectrometry (HPLC-ESI-MS/MS) was performed (analysis performed by the Laboratory of Pesticides Toxicology, Benaki Phytopathological Institute of Athens). The limit of detection was $0.45 \mu \mathrm{g} / \mathrm{kg}$ and the limit of quantification was $1.35 \mu \mathrm{g} / \mathrm{kg}$. The analysis showed final imadicloprid concentrations of $2.1 \mu \mathrm{g} / \mathrm{kg}$ in the sugar solution and $2.7 \mu \mathrm{g} / \mathrm{kg}$ in the pollen pastry.

\subsection{Development of the HPGs}

The experiments started on August 15, 2009, when combs with emerging honeybees were placed in the incubator and the emerging honeybees were introduced into the cages. On the 9th day post-caging, 20 honeybees were collected from the untreated and treated cages (10 from each group) for HPG analysis on the 9th and again on the 14th day after the honeybees were placed in the cages. Honeybee heads were dissected in insect saline solution (Berger and Carmargo Abdalla 2005). Part of the HPGs were removed, placed in an electrophoresis stain (Coomassie brilliant blue dye R250) (Rhodes and Somerville, 2003) for $4 \mathrm{~s}$ and then on a microscopic slide (without a cover slip) to be photographed under a dissecting microscope. We used an image analysis system to capture and store the images, and later measure the diameters of the acini using Image Pro-Plus software. Acini diameter was measured twice and averaged. About 300 acini were measured in each of the four groups of honeybees (treated and untreated honeybees, each at 9 and 14 days old).

\subsection{Respiratory rhythm}

Also at the 9th day post caging, 20 honeybees were tested for respiratory activity. The method for recording the respiratory rhythm in vivo has been described elsewhere (Zafeiridou and Theophilidis 2006), but some details are also given here. The honeybees were fixed with the ventral part of the thorax and the abdomen on a small platform of nontoxic wax (Genco, Tackiwax) in the centre of a Petri dish. Care was taken to leave most of the spiracles open. Then, a micropin to the probe of an isometric force displacement transducer (Grass 103, Grass Company, USA) was attached and gently connected to the edge of the second or third tergite. The analog signal of the transducer was digitized at 1,000 samples per second (A/D converter, KPCI-3102, Keithley Instruments Inc., USA) and stored in a computer using appropriate software (Labview, National Instruments 5.1). The respiratory rhythm of honeybees was recorded continuously for $1-2 \mathrm{~h}$, after 1-h recovery from the fixation process under an ambient temperature of about $27^{\circ} \mathrm{C}$. The honeybees were not fed during the recovery period and the subsequent recording of their respiratory rhythm. For the rhythmic respiratory activity, which corresponds to the coordinated contraction of respiratory muscles and it is controlled by the CPG, the frequency of the contractions was recorded, estimated from the time interval between successive contractions in hertz. For the discrete bursting activity, the burst internal frequency (in hertz), the inter-burst interval (in 
second), and the duration of the bursts (in second) was also measured using Labview software.

\subsection{Food consumption}

Sugar solution consumption was calculated as microliter/honeybee/day, and pollen consumption was calculated as milligram/honeybee/day, over a total of 14 days. Any dead honeybees were removed and counted whenever the cages were inspected.

\subsection{Statistical analysis}

Statistical analysis was performed using SPSS statistical package. A general linear model-repeated measures design was used to analyze data related to pollen and sugar solution consumption, and a oneway ANOVA design was used to analyze the logtransformed data related to acinus diameter, followed by a Tukey's B post hoc test to detect significant differences among the acini groups. An unpaired $t$ test with Welch correction (GraphPaD Instat Software) was used to compare mean respiratory parameters between honeybees exposed to imidacloprid (treated) and unexposed honeybees (untreated).

\section{RESULTS}

\subsection{Development of the HPGs}

Figure 1 shows computer microphotographs of the HPGs of 9-day-old honeybees. The acini

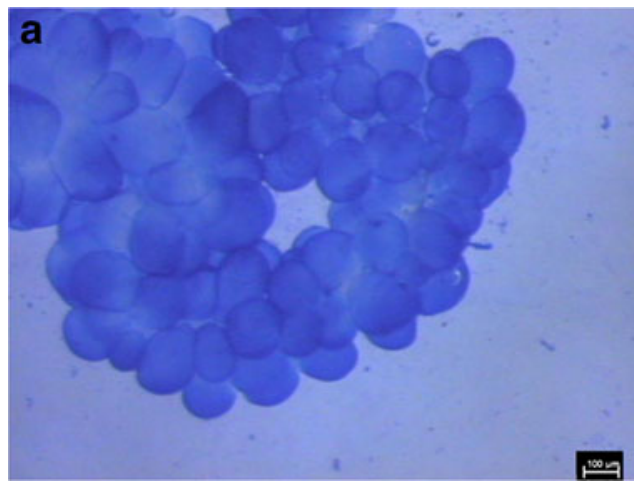

of 14-day-old honeybees were significantly smaller than those of 9-day-old honeybees for both treated (control) and untreated honeybees (ANOVA $F=633.3 ; P<0.001$; Figure 2). The acini of 14-day-old control honeybees were $19.68 \%$ smaller than those of 9-day-old control honeybees (mean $\pm \mathrm{SE}=117.55 \pm 0.78$ and $146.36 \pm 0.97$, respectively) and the acini of 14 day-old treated honeybees were $21.33 \%$ smaller than those of 9-day-old treated honeybees (mean $\pm \mathrm{SE}=98.36 \pm 0.65$ and $125.03 \pm 0.75$, respectively) Furthermore, 9-day-old treated honeybees had 14.5\% smaller acini than 9day-old control honeybees and 14-day-old treated honeybees had $16.3 \%$ smaller acini than 14-day-old control honeybees (ANOVA $F=633.3 ; P<0.001$; Figure 2).

\subsection{Respiratory rhythm}

The AVM of honeybees generally appeared to alternate between discrete bursts of respiratory activity (Figure 3a, first half) and continuous respiratory movements that made up longerlasting bursts (Figure 3a, second half) in both imidacloprid-treated and untreated honeybees. There was no significant difference in the mean internal frequency estimated for continuous respiratory movements, like those shown in the second half of Figure 3a, between imidaclopridtreated and untreated honeybees (see also Table I).

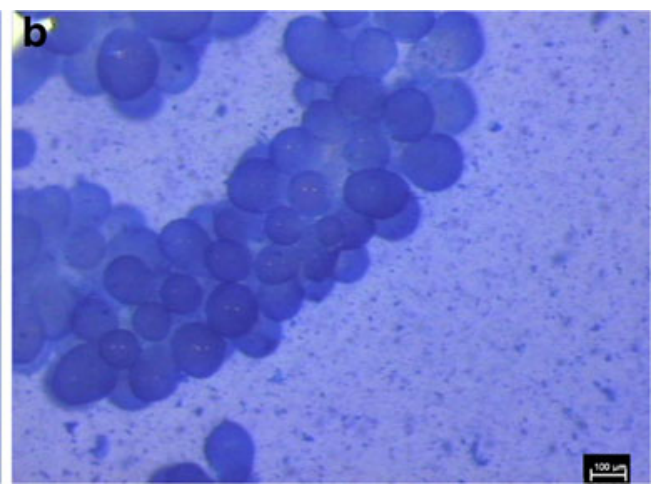

Figure 1. Computer microphotographs of HPGs of: a nine-day-old untreated honeybee, b nine-day-old treated honeybee. Scale bar represents $100 \mu \mathrm{m}$. 

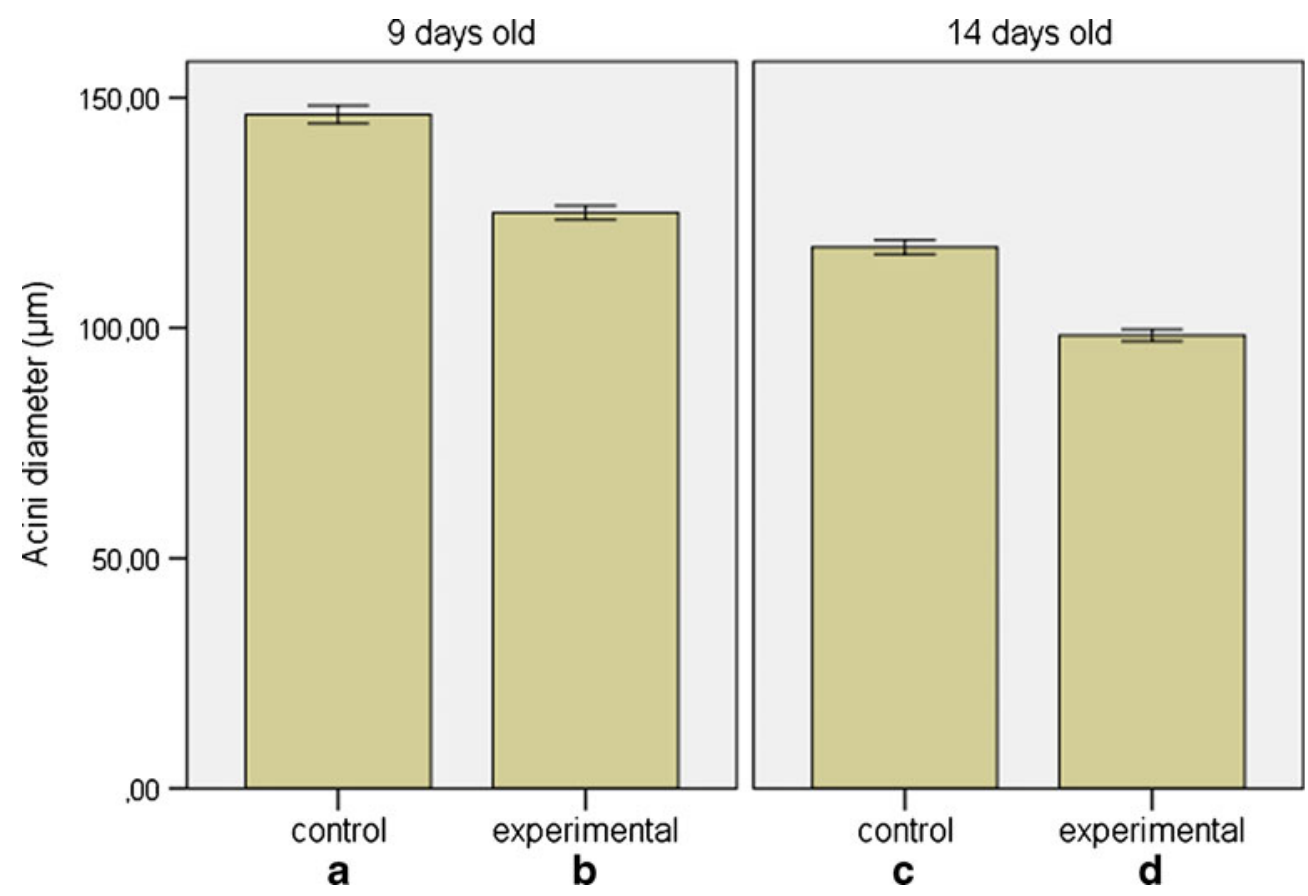

Figure 2. Acini diameter (in micrometer) (mean $\pm \mathrm{SD})$ of 9- and 14-day-old untreated and treated honeybees. Different letters below the bars denote significant differences between the groups, $P<0.001$.

On the other hand, imidacloprid significantly affected the bursting pattern of AVMs by causing a $59.4 \%$ increase in the inter-burst interval from 4.56 to $7.27 \mathrm{~s}$ (Table I and Figure 3c). Therefore, fewer AVM bursts were recorded per minute from imidacloprid-treated honeybees (Figure 3c) than from untreated honeybees (Figure $3 b$ ). In addition, there was a $56.99 \%$ decrease in the mean duration of AVM bursts, from 3.53 to $1.52 \mathrm{~s}$ (Table I). Taken together, these effects indicate a significant inhibitory effect on the generation of AVM bursts. There was no significant difference in internal frequency of AVM bursts between imidacloprid-treated and untreated honeybees (Table I).

\subsection{Food consumption}

Pollen consumption per honeybee per day is shown in Figure 4. There was no significant difference in the amount of pollen consumed by treated and untreated honeybees $(F=0.354$, n.s.). Pollen was consumed by the honeybees mainly during the first 10 days of their adult life, (from 15th to the 25th of August) which corresponds with the HPG development period, and it was decreased to negligible amounts later on. Treated and untreated honeybees also consumed similar quantities of sugar solution (Figure 5, $F=1.153$, n.s.). Honeybees tended to consume larger quantities of sugar solution after the 10th day of adult life, when they almost stopped taking pollen (Figure 5). Treated honeybees consumed about $27 \mathrm{mg}$ of pollen pastry (and $0.073 \mathrm{ng}$ of imidacloprid) and $96 \mu \mathrm{L}$ of sugar solution (corresponding to $0.036 \mathrm{~g}$ of sugar and $0.17 \mathrm{ng}$ of imidacloprid) over the first 10 days of their life (absolute amounts might be slightly more as water evaporation was not taken into account).

\section{DISCUSSION}

Our results showed that continuous exposure to imidacloprid during the first 14 days of adult life in honeybees negatively affects HPG devel- 


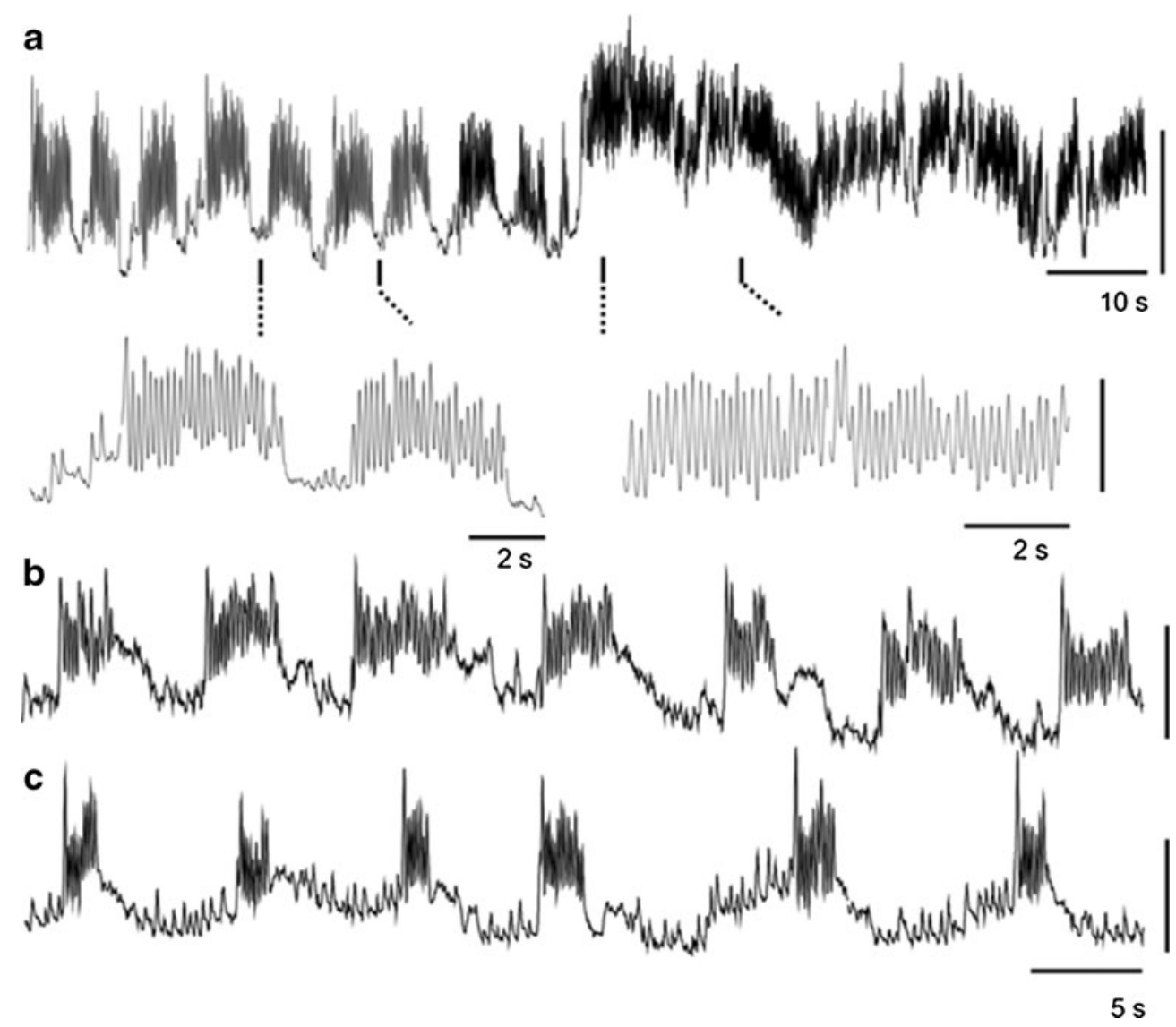

Figure 3. Tension recordings of the respiratory contractions from the dorsal region of the second or third abdominal segment of an immobilized honeybee. a Untreated honeybees. The transition from bursting to continuous respiration contractions. Parts of the recordings were expanded to show the two respiratory patterns in detail. b Untreated honeybees. Rhythmic respiratory bursting activity. c Imidacloprid-treated honeybees. Rhythmic respiratory bursting activity; vertical calibration mark $1.05 \mathrm{~N}$.

opment and respiratory function. The doses of imidacloprid given to honeybees $(2.1 \mu \mathrm{g} / \mathrm{kg}$ for the sugar solution and $2.7 \mu \mathrm{g} / \mathrm{kg}$ for pollen) are representative of the amounts found in the nectar and pollen honeybees collected from plants that had been seed dressed with imidacloprid, such as sunflower and maize (Stork 1999; Bonmatin et al. 2003). Chronic exposure measured at 9 and 14 days is comparable to natural conditions in which honeybees are continuously exposed to pollen and/or to nectar from these seed-dressed plants that bloom for long periods. In reality, in the field, the exposure period could last several weeks, given that crop plants do not flower simultaneously and given the large surface areas in agricultural environments. Therefore, imidacloprid or any other neonicotinoid present in the pollen and nectar throughout flowering will be brought to the colony continuously until flowering is finished. Furthermore, the insecticide will be stored in the hive and therefore available over longer periods.

\subsection{HPGs}

Our protocol was proved to be appropriate for measuring HPG activity, as average acini 
Table I. Regular bursting respiratory activity of the untreated honeybees and honeybees treated with imidacloprid, oral administration. The main parameters of the rhythmic bursts (internal frequency, inter-burst interval, burst duration) are given as mean \pm S.E.M and expressed as a percentage of the untreated parameters.

\begin{tabular}{cllllll}
\hline & $\begin{array}{l}\text { Internal } \\
\text { frequency } \\
(\mathrm{Hz})\end{array}$ & $\begin{array}{l}\text { Internal } \\
\text { frequency } \% \\
\text { control }\end{array}$ & $\begin{array}{l}\text { Inter-burst } \\
\text { interval }\end{array}$ & $\begin{array}{l}\text { Inter-burst } \\
\text { interval \% } \\
\text { control }\end{array}$ & $\begin{array}{l}\text { Burst } \\
\text { duration }\end{array}$ & $\begin{array}{l}\text { Burst } \\
\text { duration \% } \\
\text { control }\end{array}$ \\
\hline $\begin{array}{c}\text { Honeybees } \\
\text { untreated }\end{array}$ & $\begin{array}{l}5.41 \pm 0.18 \\
(n=39 / 6)\end{array}$ & 100.0 & $\begin{array}{l}4.56 \mathrm{a} \pm 0.19 \\
(n=435 / 6)\end{array}$ & 100.0 & $\begin{array}{l}3.53 \mathrm{~b} \pm 0.11 \\
(n=397 / 6)\end{array}$ & 100.0 \\
$\begin{array}{c}\text { Honeybees } \\
\text { treated with } \\
\text { imidacloprid }\end{array}$ & $\begin{array}{l}5.40 \mathrm{~ns} \pm 0.18 \\
(n=46 / 4)\end{array}$ & 99.8 & $\begin{array}{l}7.27 \mathrm{~b} \pm 0.28 \\
(n=146 / 4)\end{array}$ & 159.4 & $\begin{array}{l}1.52 \mathrm{a} \pm 0.05 \\
(n=180 / 4)\end{array}$ & 43.01 \\
\hline
\end{tabular}

$\mathrm{a}$ and $\mathrm{b}$ denote significant differences between treated and untreated bees at $P<0.05$

$n$ number of bursts/number of honeybees, $n s$ not significant compared to untreated

diameter in control honeybees was similar to that of honeybees of the same age in other studies (Lass and Crailsheim 1996; Hrassnigg and Crailsheim 1998; Malone et al. 2004;
Deseyn and Billen 2005). Our results obtained after continuous exposure to imidacloprid (until 14 days) confirm the effects reported by Smodis-Skerl and Gregorc (2010) and Heylen
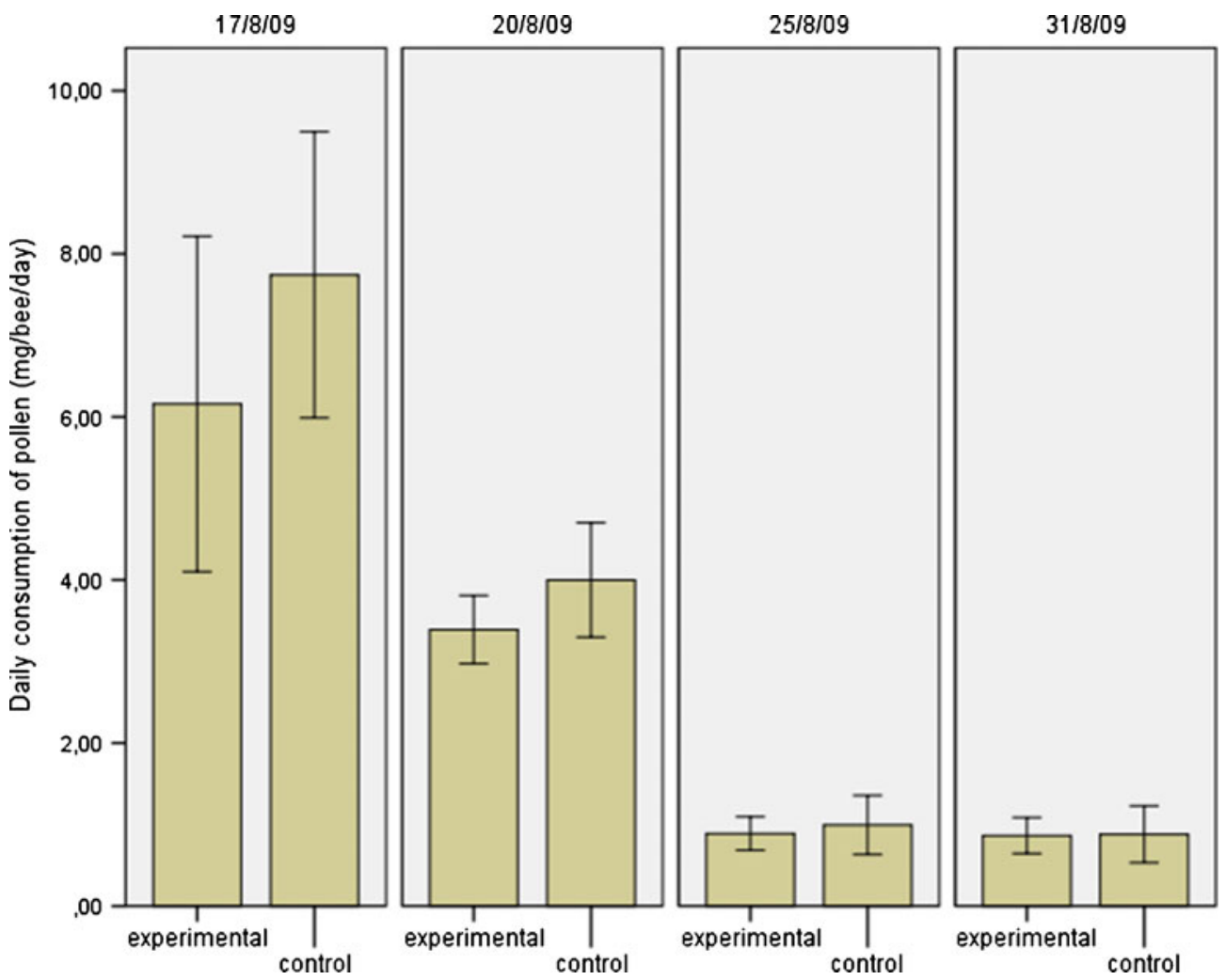

Figure 4. Mean ( \pm SEM) pollen consumption (milligram) per honeybee per day. Consumption per day is the mean for the given period between the days indicated on the figure (2-, 3-, 5- and 6-day intervals). 


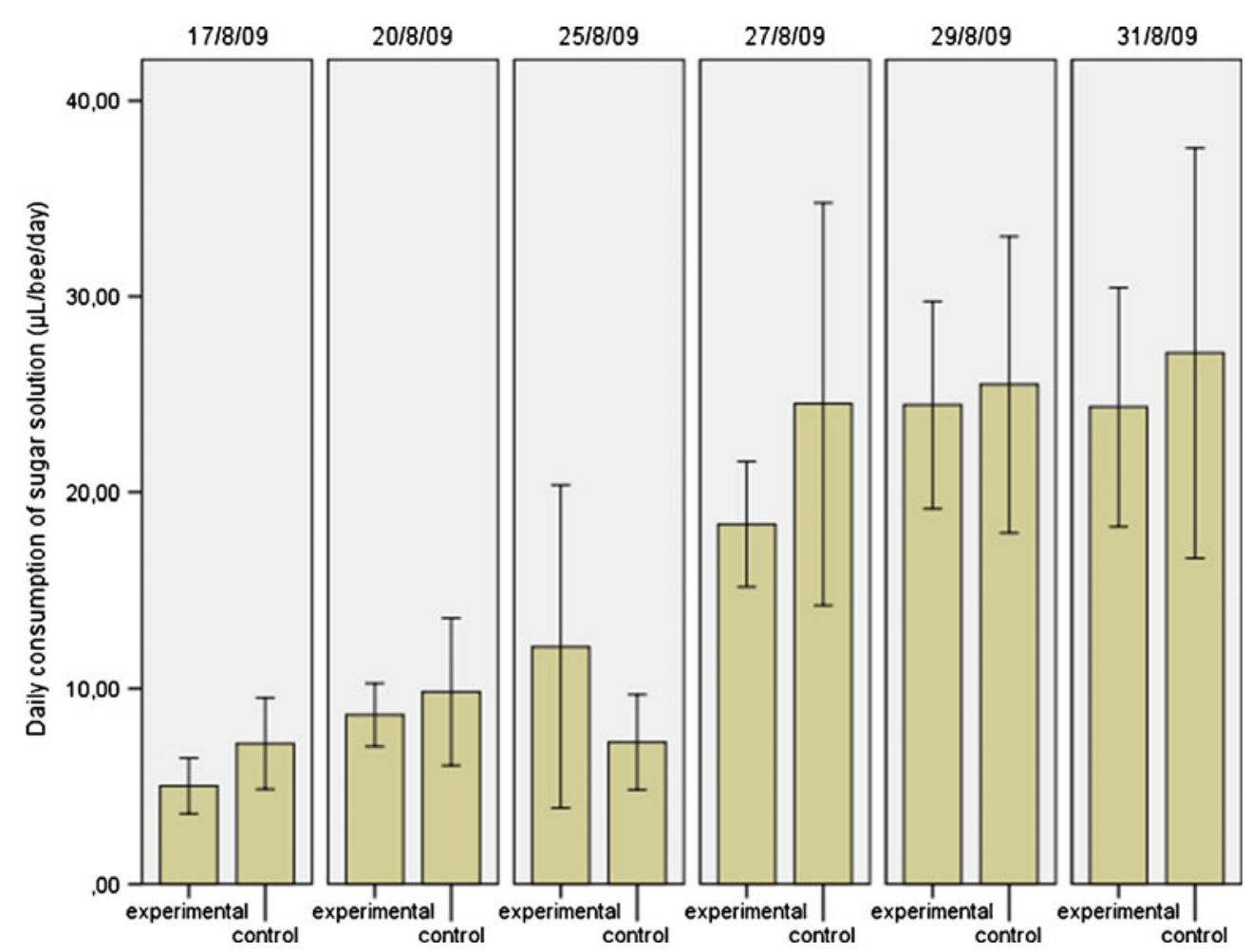

Figure 5. Mean ( \pm SEM) sugar solution consumption (microliter) per honeybee, per day. Consumption per day is the mean for the given period between the days indicated on the figure (2-, 3-, 5-, 2-, 2- and 2-day intervals).

et al. (2010) for a short exposure period (13 days), and demonstrate that the glands do not recover, even after a longer period. The mean acini diameter of treated, 9-day-old honeybees was $14.5 \%$ smaller than that of 9-day-old control honeybees and the mean acini diameter of treated, 14-day-old honeybees was $16.3 \%$ smaller than that of 14-day-old control honeybees. Therefore, the toxicity of sublethal doses of imidacloprid could appear after either acute or chronic exposure.

As the size of the HPG lobes (that is, the acini diameter) is an indirect indication of HPG activity (Hrassnigg and Crailsheim 1998; Deseyn and Billen 2005), we can infer that the smaller acini of HPGs in honeybees exposed to imidacloprid could influence the protein synthesis of the glands, and therefore lead to nurse honeybees producing royal jelly of lesser quality and/or quantity. Moreover, it has been shown that degeneration of these glands normally accompanies a worker's shift from nest to field activities (Ohashi et al. 1997). Therefore, it may be hypothesized that nurse honeybees with reduced glands might become foragers in less time than they would have if their glands had developed normally and, as a result, the population of nurses will decline. One of the consequences could be a reduced production of brood, with negative effects for the colony's development. Normally honeybees start becoming foragers after the 13-14th day of their life (Ohashi et al. 1997) and this activity normally reaches its peak at about the 23rd day of the honeybee's life (Winston 1987). If they stop nursing 5 days earlier, this is almost $1 / 3$ of their enclosure life, which cannot be regarded as negligible compared to the total lifespan of a honeybee. Eventually they will live 5 day less than untreated honeybees. Precocious swift 
from nursing to foraging is predicted in the model built by Khoury et al. (2011) as an indirect effect of foragers' death, leading to an acceleration of colony collapse.

In fact, in a more recent study, we observed a decrease of adult honeybee population, although not only of foragers, as a result of imidacloprid use in a field of seed-dressed cotton plants (Hatjina et al., unpublished data). It is believed that both parameters, HPGs size reduction and adult honeybee deaths, fit well in the model by Khoury et al. (2011), predicting an acceleration of colony failure although they might not be the only ones affecting demography changes in a colony. Furthermore, delayed effects can also be very harmful to the colony especially when they occur early in spring while the colony is developing, as this is when most of the stored contaminated pollen is consumed.

\subsection{Consumption of food}

Pollen consumption was high during the period of HPG development consistent with Hrassnigg and Crailsheim (1998) and it almost completely stopped later on. Contrary to pollen, honeybees only consumed small quantities of sugar solution during the period of HPG development but increased sugar consumption later on. However, similar to pollen, sugar solution was used in equal amounts by both treated and untreated honeybees, as has also been shown in other studies (Ramirez-Romero et al. 2005). Therefore, in our experimental conditions the decreased size of the acini cannot be attributed to insufficient consumption of food by treated honeybees, but rather to the presence of imidacloprid.

In natural conditions, nurse honeybees could also participate in heating of the brood. The brood-attending honeybees require energy to maintain the brood temperature at about $34{ }^{\circ} \mathrm{C}$ from April to October in temperate regions (Simpson 1961; Seeley and Heinrich 1981; Heinrich 1985). Rortais et al. (2005) estimated the amounts of sugar (contained in nectar or honey), pollen and imidacloprid consumed by nurse or brood-attending honeybees. The nurses, for example, consume about $65 \mathrm{mg}$ of pollen over 10 days, corresponding to a total $0.2 \mathrm{ng}$ of imidacloprid (at a concentration of $3.4 \mu \mathrm{g} / \mathrm{kg}$ of pollen, Bonmatin et al. 2001). In our experimental conditions, young honeybees consumed only $31 \mathrm{mg}$ of pollen, corresponding to a total of $0.08 \mathrm{ng}$ of imidacloprid (at a concentration of $2.7 \mu \mathrm{g} / \mathrm{kg}$ of pollen) over 14 days, because they were kept in an incubator and reared no brood. Also according to Rortais et al. (2005), nurse honeybees consume 272$400 \mathrm{mg}$ of sugar (depending of the temperature of the hive), corresponding to a total of 1.3$1.9 \mathrm{mg}$ of imidacloprid (at a concentration of $1.9 \mu \mathrm{g} / \mathrm{kg}$ of nectar, Stork 1999). For the duration of our experiment, honeybees consumed only $86 \mathrm{mg}$ of sugar, corresponding to a total of $0.4 \mathrm{ng}$ of imidacloprid (at a concentration of $1.9 \mu \mathrm{g} / \mathrm{kg}$ of nectar). From our results, it is obvious that the quantities of imidacloprid consumed by treated honeybees through pollen and sugar solution intake were far less than that estimated for honeybees in natural conditions, but there were nevertheless obvious adverse effects on the HPGs.

\subsection{Respiratory rhythm}

Two alternating patterns of AVM in restrained honeybees were observed: discontinuous AVM or discrete bursts and continuous AVM. The discontinuous pattern of AVM is typical of resting honeybees (Kaiser 1988; Lighton and Lovergrove 1990; Kovac et al. 2007), while the continuous pattern of fast AVM has been observed in active honeybees and other Hymenoptera that are performing brood incubation tasks (Ishay 1972; Heinreich 1972; Bujok et al. 2002). In other intact insects, like locusts, continuous AVM is induced by sensory feedback (Bustami and Hustert 2000). It seems that in our case, the CPG underlying the respiratory rhythm of intact restrained honeybees was in standby position, which permitted transition into continuous AVM, but the responsible factors for this transition were not further investigated. Furthermore, the recording method used here is reliable, as the duration of AVM 
bursts $(3.5 \mathrm{~s})$ is within the range of the average (1.3-3.7 s) reported for typical AVM of exclusively resting honeybees, using a completely different, non-invasive recording method (Kovac et al. 2007).

In the present study, specific parameters like the frequency of continuous AVM and the duration; interval and internal frequency of the AVM bursts were used as an indication of the functional condition of the cholinergic synapses that mediate respiratory rhythm after the honeybees were exposed to low concentrations of imidacloprid. Both bursting and continuous AVM were recorded in both imidaclopridtreated and untreated honeybees. Thus, it is unlikely that imidacloprid induces excitation of AVM and causes the subsequent transition from bursting to continuous AVM activity. In addition, the frequency of continuous AVM and the internal frequency of bursts were not significantly different in the two groups of honeybees. However, imidacloprid reduced the capacity for generating normal bursts of AVM by significantly reducing the rate of burst production (increase in inter-burst interval) and burst duration. The decrease in the rate of AVM bursts suggests that imidacloprid could act at the level of the CNS, since the rate of AVM burst generation is controlled by neural networks (CPG) in the insect CNS (Bustami and Hustert 2000). This could occur after imidacloprid transfer from the haemolymph compartment to the abdomen, thorax, and head (Suchail et al. 2004), where CPGs for respiration are thought to be located. Fewer and shorter AVM bursts induced by imidacloprid could have a direct suppressive effect on the gas exchange of carbon dioxide and oxygen as well as on the metabolic activity of honeybees, since a correlation of metabolic and respiratory activity occurs in insects (Contreras and Bradley 2010).

\subsection{Conclusion}

While numerous studies have focussed on the behavioural effects of imidacloprid in honeybees, very few have focussed on the physiological effects of this insecticide. Our study demonstrates that in laboratory conditions, imidacloprid affects the development of HPGs and patterns of respiration rhythm and shows that the physiological effects must also be considered because they have negative consequences both for the individual honeybees and for the overall development of the colony.

\section{ACKNOWLEDGMENTS}

This work was supported by a joint project from the EU and the Greek Ministry of Agricultural Development and Food (2008-2010) and by a Greek-French bilateral collaboration project, PLATON 09 FR75. We thank Dimitra Fouka, laboratory technician in Hellenic Institute of Apiculture, for technical assistance. We are also profoundly indebted to Sharilynn Wardrop, for stylistic and linguistic improvements as well to the anonymous reviewers for valuable suggestions.

Des doses sublétales d'imidaclopride réduisent la taille des glandes hypopharyngiennes et agissent sur le rythme respiratoire des abeilles

Insecticide / abeille / essai en laboratoire / respiration / glande salivaire

Subletale Imidaclopriddosierungen verringern die Größe der Futtersaftdrüsen und den Atemrhythmus von Honigbienen in vivo

\section{Imidacloprid / Honigbiene / Futtersaftdrüse / Atemrhythmus}

\section{REFERENCES}

Alaux, C., Brunet, J.L., Dussaubat, C., Mondet, F., Tchamitchan, S., Cousin, M., Brillard, J., Baldy, A., Belzunces, L.P., Le Conte, Y. (2010) Interactions between Nosema microspores and a neonicotinoid weaken honeybees (Apis mellifera). Environ. Microbiol. 12(3), 774-782

Babendreier, D., Kalbere, R.N.M., Romeis, J., Fluri, P., Mulligan, E., Bigler, F. (2005) Influence of Bttransgenic pollen, Bt-toxin and protease inhibitor (SBTI) ingestion on development of the hypopharyngeal glands in honeybees. Apidologie 36, 585-594

Benson, J.A. (1992) Electrophysiological pharmacology of the nicotinic and muscarinic cholinergic responses of isolated neuronal somata from locust thoracic ganglia. J. Exp. Biol. 170, 203-233 
Berger, B., Carmargo Abdalla, F. (2005) Braz. J Morphol. Sci 22(1), 1-4

Bonmatin, J.M., Moineau, I., Lecoublet, S., Colin, M. E., Fléché, C., Bengsch E. R. (2001) Neurotoxiques systémiques: Biodisponibilité, toxicité et risques pour les insectes pollinisateurs - le cas de l'imidaclopride. In Proceedings of the 30éme Congrés du Groupe Français des Pesticides, Produits phytosanitaires; Couderchet, M., Eullaffroy, P., Vernet, G., Eds.; Presses Universitaires de Reims: Reims, France, pp: 175-181.

Bonmatin, J.M., Moineau, I., Charvet, R., Fleche, C., Colin, M.E., Bengsch, E.R. (2003) A LC/APCI-MS/ MS method for analysis of imidacloprid in soils, in plants, and in pollens. Anal. Chem. 7, 2027-2033

Bonmatin, J.M., Marchand, P.A., Charvet, R., Moineau, I., Bengsch, E.R., Colin, M.E. (2005) Quantification of imidacloprid uptake in maize crops. J. Agric. Food. Chem. 53, 5336-5341

Bortolotti, L., Montanari, R., Marcelino, J., Medrzycki, P., Maini, S., Porrini, C. (2003) Effects of sub-lethal imidacloprid doses on the homing rate and foraging activity of honey bees. Bull. Insectology 56(1), 63-67

Breer, H., Sattelle, D.B. (1987) Molecular properties and functions of insect acetylcholine receptors. J. Insect Physiol. 33, 771-790

Brown, L.A., Ihara, M., Buckingham, S.D., Matsuda, K., Sattelle, B.D. (2006) Neonicotinoid insecticides display partial and super agonist actions on native insect nicotinic acetylcholine receptors. J. Neurochem. 99, 608-615

Buckingham, S.D., Lapied, B., Corronc, H.L., Grolleau, F.D., Sattelle, D.B. (1997) Imidacloprid actions on insect neuronal acetylcholine receptors. J. Exp. Biol. 200, 2685-2692

Bujok, B., Kleinhenz, M., Fuchs, S. (2002) Hot spots in the bee hive. Naturwissenschaften 89, 229-301

Bustami, H.P., Hustert, R. (2000) Typical ventilatory pattern of the intact locust is produced by the isolated CNS. J. Insect Physiol. 46, 1285-1293

Chapman, R.F. (1988) Sensory aspects of host-plant recognition by Acridoidea: questions associated with the multiplicity of receptors and variability of response. J. Insect Physiol. 34, 167-74

Chauzat, M.P., Faucon, J.P., Martel, A.C., Lachaize, J., Cougoule, N., Aubert, M. (2006) A survey of pesticide residues in pollen loads collected by honey bees in France. J. Econ. Entomol. 99, 253-262

Chauzat, M.P., Martel, A.C., Cougoule, N., Porta, P., Lachaize, J., Zeggane, S., Aubert, M., Carpentier, P., Faucon, J.P. (2011) An assessment of honeybee colony matrices, Apis mellifera (Hymenoptera Apidae) to monitor pesticide presences in continental France. Environ. Toxicol. Chem. 30, 103-111

Colin, M.E., Bonmatin, J.M., Moineau, I., Gaimon, C., Brun, S., Vermandere, J.P. (2004) A method to quantify and analyze the foraging activity of honey bees: relevance to the sublethal effects induced by systemic insecticides. Arch. Environ. Contam. Toxicol. 47, 387-395

Contreras, H.L., Bradley, T.J. (2010) Transitions in insect respiratory patterns are controlled by changes in metabolic rate. J. Insect Physiol. 56, 522-528

Crailsheim, K., Stolberg, E. (1989) Influence of diet, age and colony condition upon intestinal proteolytic activity and size of the hypopharyngeal glands in the honeybee (Apis mellifera L.). J. Insect Physiol 35, 595-602

Crailsheim, K., Schneider, L.H.W., Hrassnigg, N., Bühlmann, G., Brosch, U., Gmeinbauer, R., Schöffmann, B. (1992) Pollen consumption and utilization in worker honeybees (Apis mellifera carnica): Dependence on individual age and function. J. Insect Physiol. 38, 409-419

Decourtye, A., Lacassie, E., Pham-Delegue, M.H. (2003) Learning performances of honeybees (Apis mellifera L) are differentially affected by imidacloprid according to the season. Pest Manag. Sci. 59, 269-278

Decourtye, A., Devillers, J., Cluzeau, S., Charreton, M., Pham-Delegue, M.H. (2004a) Effects of imidacloprid and deltamethrin on associative learning in honeybee under semi-field and laboratory conditions. Ecotoxicol. Environ. Saf. 57, 410-419

Decourtye, A., Armengaud, C., Renou, M., Devillers, J., Cluzeau, S., Gauthier, M., Pham-Delegue, M.H. (2004b) Imidacloprid impairs memory and brain metabolism in the honeybee (Apis mellifera L.). Pest. Biochem. Physiol. 78, 83-92

Deseyn, J., Billen, J. (2005) Age-dependent morphology and ultrastructure of the hypopharyngeal gland of Apis mellifera L. workers (Hymenoptera, Apidae). Apidologie 36, 49-57

Fluri, P., Lucher, M., Wille, H., Gerig, L. (1982) Changes in weight of the pharyngeal gland and haemolymph titres of juvenile hormone protein and vitellogenin in worker honey bees. J. Insect Physiol. 28, 61-68

Girolami, V., Mazzon, L., Squartini, A., Mori, N., Marzaro, M., Di Bernardo, A., Greatti, M., Giorio, C., Tapparo, A. (2009) Translocation of neonicotinoid insecticides from coated seeds to seedling guttation drops: a novel way of intoxication for bees. J. Econ. Entomol. 102(5), 1808-1815

Girolami, V., Marzaro, M., Vivan, L., Mazzon, L., Greatti, M., Giorio, C., Marton, D., Tapparo, A. (2011) Fatal powdering of bees in flight with particulates of neonicotinoids seed coating and humidity implication. J. Appl. Entomol. 136(1-2), 17-26

Greatti, M., Sabatini, A.G., Barbattini, R., Rossi, S., Stravisi, A. (2003) Risk of environmental contamination by the active ingredient imidacloprid used for corn seed dressing. Preliminary results. Bull. Insectology 56, 69-72

Greatti, M., Barbattini, R., Stravisi, A., Sabatini, A.G., Rossi, S. (2006) Presence of the a.i. imidacloprid on vegetation near corn fields sown with Gaucho® dressed seeds. Bull. Insectology 59, 99-103 
Guez, D., Suchail, S., Gauthier, M., Maleszka, R., Belzunces, L.P. (2001a) Sublethal effects of imidacloprid on learning and memory in honeybees. In: Proceedings of the 7th International Symposium "Hazards of pesticides to bees", September 7-9, 1999, Avignon, France (Belzunces L. P., Pelissier C., Lewis G. B., Eds). Les Colloques de l'INRA, 98, 279.

Guez, D., Suchail, S., Gauthier, M., Maleszka, R., Belzunces, L.P. (2001b) Contrasting effects of imidacloprid on habituation in 7- and 8- day-old honeybees (Apis mellifera). Neurobiol. Learn. Mem. 76, 183-191

Haydak, M.H. (1970) Honey bee nutrition. Annu. Rev. Entomol. 15, 143-156

Heinrich, B. (1972) Physiology of brood incubation in the bumblebee queens, Bombus vosnesenskii. Nature 239, 223-225

Heinrich, B. (1985) The social physiology of temperature regulation in honeybees, in: Holldobler J.M., Lindauer G. (Eds.), Experimental Behavioral Ecology. Fortschr. Zool. 31, 393-406

Henry, M., Beguin, M., Requir, F., Rollin, O., Odoux, JF., Aupinel, P., Aptel, J., Tchamitchian, S., Decourtye, A. (2012) A common pesticide decreases foraging success and survival in honey bees. Scienc 336(6079):348-350. doi:10.1126/science.1215039.

Heylen, K., Gobin, B., Arckens, L., Huybrechts, R., Billen, J. (2010) The effects of four crop protection products on the morphology and ultrastructure of the hypopharyngeal gland of the European honeybee, Apis mellifera. Apidologie 42, 103-116

Hrassnigg, N., Crailsheim, K. (1998) The influence of brood on the pollen consumption of worker bees (Apis mellifera L.). J. Insect. Physiol. 44, 393-404

Jeschke, P., Nauen, R., Schindler, M., Elbert, A. (2011) Overview of the Status and Global Strategy for Neonicotinoids. J. Agric. Food Chem. 59(7), 2897-2908

Ishay, J. (1972) Thermoregulatory pheromones in wasps. Experienta 28, 1185-1187

Kaiser, W. (1988) Busy bees need rest, too: behavioural and electromyographical sleep signs in honeybees. J. Comp. Physiol. A 163, 565-584

Khoury, D.S., Myerscough, M.R., Barron, A.B. (2011) A quantitative model of honey bee colony population dynamics. Plos One 6, e18491

Kirchner, W.H. (1999) Mad-bee-disease? Sublethal effects of Imidacloprid (Gaucho ${ }^{(\mathbb{R})}$ ) on the behavior of honey-bees. Apidologie 30, 422

Knecht, D., Kaatz, H.H. (1990) Patterns of larval food production by hypopharyngeal glands in adult worker honey bees. Apidologie 21, 457-468

Kovac, H., Stabentheiner, A., Hetz, S.K., Petz, M., Crailsheim, K. (2007) Respiration of resting honeybees. J. Insect. Physiol. 53, 1250-1261

Kühnholz, S., Seeley, T.D. (1997) The control of water collection in honey bee colonies. Behav. Ecol. Sociobiol. 41, 407-422
Lambin, M., Armengaud, C., Raymond, S., Gauthier, M. (2001) Imidacloprid induced facilitation of the proboscis extension reflex habituation in the honeybee. Arch. Insect Biochem. Physiol. 48, 129-134

Lass, A., Crailsheim, K. (1996) Influence of age and caging upon protein metabolism, hypopharyngeal glands and trophallactic behavior in the honey bee (Apis mellifera L). Insectes Soc. 43, 347-358

Lighton, J.R.B., Lovegrove, B.G. (1990) A temperatureinduced switch from diffusive to connective ventilation in the honeybee. J. Exp. Biol. 154, 509-516

Maini, S., Medrycki, P., Porrini, C. (2010) The puzzle of honey bee losses: a brief review. Bull. Insectology 63, 153-160

Malone, L.A., Todd, J.H., Burgess, E.P.J., Christeller, J.T. (2004) Development of hypopharyngeal glands in adult honey bees fed with a Bt toxin, a biotin binding protein and a protease inhibitor. Apidologie 35, 655-664

Marzaro, M., Vivan, L., Targa, A., Mazzon, L., Mori, N., Greatti, M., Toffolo, E.P., Di Bernardo, A., Giorio, C., Marton, D., Tapparo, A., Girolami, V. (2011) Lethal aerial powdering of honey bees with neonicotinoids from fragments of maize seed coat. Bull. Insectology 64, 119-126

Matsuda, K., Buckingham, S.D., Kleier, D., Rauh, J.J., Grauso, M., Sattelle, D.B. (2001) Neonicotinoids: insecticides acting on insect nicotinic acetylcholine receptors. Trends Pharmacol. Sci. 22, 573-580

Matsuda, K., Shimomura, M., Ihara, M., Akamatsu, M., Satelle, D.B. (2005) Neonicotinoids show selective and diverse actions on their nicotinic receptor targets: electrophysiology, molecular biology, and receptor modelling studies. Biosci. Biotechnol. Biochem 69, 1442-1452

Nicolas, H., Badre, M., Martin, E., Robin, L., Cooper, T. (2005) The physiological and behavioral effects of carbon dioxide on Drosophila melanogaster larvae. Comp. Biochem. Physiol. A 140, 363-376

Ohashi, K., Natori, S., Kubo, T. (1997) Change in the mode of gene expression of the hypopharingeal gland cells with an age-dependent role change of the worker honeybee Apis mellifera L. Eur. J. Biochem. 249, 797-802

Ramirez, J.M., Pearson, K.G. (1989) Distribution of intersegmental interneurones that can reset the respiratory rhythm of the locust. J. Exp. Biol. 141, $151-176$

Ramirez-Romero, R., Chaufaux, J., Pham-Delegue, M.H. (2005) Effects of Cry $1 \mathrm{Ab}$ protoxin, deltamethrin and imidacloprid on the foraging activity and the learning performances of the honeybee Apis mellifera, a comparative approach. Apidologie 36, 601611

Rhodes, J.W., Somerrville, D.C. (2003) Introduction and early performance of queen bees. Report : Rural Industries Research \& Development Corporation, NSW Agriculture Pub\# 03/049. 
Rortais, A., Arnold, G., Halm, M.P., Touffet-Briens, F. (2005) Modes of honeybees exposure to systemic insecticides: estimated amounts of contaminated pollen and nectar consumed by different categories of bees. Apidologie 36, 71-83

Seeley, T.D., Heinrich, B. (1981) Regulation of temperature in the nests of social insects. In: Heinrich, B. (ed.) Insect thermoregulation, pp. 159-234. Wiley, New York

Shawky, S., Abdel-Geleel, M., Aly, A. (2005) Sorption of uranium by non-living water hyacinth roots. J. Radioanal. Nucl. Chem. 265(1), 81-84

Simpson, J. (1961) Nest climate regulation in honey bee colonies. Science 133, 1327-1333

Smodiš Šker, M.I., Gregorc, A. (2010) Heat shock proteins and cell death in situ localisation in hypopharyngeal glands of honeybee (Apis mellifera carnica) workers after imidacloprid or coumaphos treatment. Apidologie 41, 73-86

Standifer, L.N. (1967) A comparison of the protein quality of pollens for growth-stimulation of the hypopharyngeal glands and longevity of honey bees, Apis mellifera. (Hymenoptera: Apidae). Insectes Soc 14, 415-426

Stork, A. (1999) A residue of 14C-NTN33893 (imidacloprid) in blossoms of sunflowers (Helianthus annus) after seed dressing, p. 56. Bayer A. G., Crop Protection Development, Institute for Metabolism Research and Residue Analysis, Leverkusen

Suchail, S., De Sousa, G., Rahmani, R., Belzunces, L. (2004) In vivo distribution and metabolization of ${ }^{14}$ Cimidacloprid in different compartments of Apis mellifera L. Pest Manag. Sci. 60, 1056-1062
Vidau, C., Diogon, M., Aufauvre, J., Fontbonne, R., Viguès, B., et al. (2011) Exposure to sublethal doses of fipronil and thiacloprid highly increases mortality of honeybees previously infected by Nosema ceranae. PLoS ONE 6(6), e 21550

Visscher, H., Brinkhuiss, H., Dilcher, D.L., Elsik, W.C., Eshet, Y., Looy, C.V., Rampino, M.R., Traverse, A. (1996) The terminal Paleozoic fungal event: Evidence of terrestrial ecosystem destabilization and collapse. Proc. Natl. Acad. Sci. USA 93, 2155-2158

Der Wang, L., Moller, F.E. (1969) Histological comparisons of the development of hypopharyngeal glands in healthy and Nosema-infect worker honey bees. J. Invertebr. Pathol. 17, 308-320

Winston, M.L. (1987) The biology of the honey bee, p. 281. Harvard University Press, Cambridge

Wolf, T.J., Schmid-Hempel, P., Ellington, C.P., Stevenson, R.D. (1989) Physiological correlates of foraging efforts in honey-bees: oxygen consumption and nectar load. Funct. Ecol. 3, 417-424

Yang, E.C., Chuang, Y.C., Chen, Y.L., Chang, L.H. (2008) Abnormal foraging behavior induced by sublethal dosage of imidacloprid in the honey bee (Hymenoptera: Apidae). J. Econ. Entomol. 101, 1743-1748

Zafeiridou, G., Theophilidis, G. (2004) The action of the insecticide imidacloprid on the respiratory rhythm of an insect: the beetle Tenebrio molitor. Neurosci. Lett. 365, 205-209

Zafeiridou, G., Theophilidis, G. (2006) A simple method for monitoring the respiratory rhythm in intact insects and assessing the neurotoxicity of insecticide. Pestic. Biochem. Physiol. 87, 211-217 